\title{
sciendo
}

\section{Homeobox B4 gene expression is upregulated by ghrelin through PI3-kinase signaling pathway in rat's bone marrow stromal cells}

\author{
Shokoufeh Taherkhani, Fatemeh Moradi, Masoumeh Hosseini, Mohsen Alipour, Hadi Feizi
}

Department of Physiology and Pharmacology, Faculty of Medicine, Zanjan University of Medical Sciences, Zanjan, Iran E-mail: hfeizik@zums.ac.ir

Objective. Ghrelin, a 28 amino acid peptide, has diverse physiological roles. Phosphatidylinositol-bisphosphate 3-kinase (PI3K) and mitogen-activated protein kinase (MAPK) are involved in some of the recognized actions of ghrelin. It has been shown that ghrelin upregulates HOXB4 gene expression but the real mechanism of this effect is not clear.

Methods. Rat bone marrow stromal cells (BMSCs) were cultured in DMEM. BMSCs were treated with ghrelin $(100 \mu \mathrm{M})$ for $48 \mathrm{~h}$. Real-time PCR for HOXB4 was performed from Control (untreated BMSCs), BG (BMSCs treated with $100 \mu \mathrm{M}$ ghrelin), PD (BMSCs treated with $10 \mu \mathrm{M}$ PD98059, a potent inhibitor of mitogen-activated protein kinase, and $100 \mu \mathrm{M}$ ghrelin), LY (BMSCs treated with $10 \mu \mathrm{M}$ LY294002, a strong inhibitor of phosphoinositide 3-kinase, and $100 \mu \mathrm{M}$ ghrelin) and SY (BMSCs treated with $10 \mu \mathrm{M}$ LY294002 plus $10 \mu \mathrm{M}$ PD98059, and $100 \mu \mathrm{M}$ ghrelin) groups. Relative gene expression changes were determined using Relative expression software tool 9 (REST 9).

Results. HOXB4 gene has been overexpressed in ghrelin-treated BMSCs ( $\mathrm{p}<0.05)$. PI3K inhibition by LY294002 significantly downregulated the ghrelin-induced overexpression of HOXB4 $(\mathrm{p}<0.05)$.

Conclusion. We can conclude that ghrelin, through PI3K/Akt pathway, may improve BMSC transplantation potency by reducing its apoptosis. Moreover, upregulating HOXB4 in BMSC and its possible differentiation to HSCs might in the future open the doors to new treatment for hematologic disorders. Therefore, activating the PI3K/Akt pathway, instead of using a non-specific inducer, could be the principal point to increase the efficiency of BMSC-based cell therapies in the future.

Key words: ghrelin, HOXB4, PI3K, MAPK, rat, BMSCs

Ghrelin, a peptide mostly produced in the stomach, is endogenous secretagogues of the growth hormone (Kojima and Kangawa 2005). The ghrelin receptor named as GHS-R1a, a G protein-coupled receptor, has been cloned in different tissues of the body (Albarran-Zeckler and Smith 2013). Since its finding, many physiological roles have been attributed to the ghrelin (van der Lely et al. 2004). During the last decade, its effects on various cell lines including stem cells have been elucidated. A couple of studies have shown the beneficiary effects of ghrelin on neurogen- esis (Moon et al. 2009; Li et al. 2013). Furthermore, some researchers have introduced this peptide as an inducer to provide cardiomyocytes from embryonic stem cells (Yang et al. 2011).

Recently, we have shown that ghrelin upregulates HOXB4 gene in rat's bone marrow stromal cells (BMSCs) (Abdanipour et al. 2018a). BMSCs are a population of mesenchymal stem cells, which are widely used in experimental and clinical cell therapy strategies (Mahmood et al. 2004). These cells have a high differentiation capability to other cells including

Corresponding author: Dr. Hadi Feizi, Department of Physiology and Pharmacology, Faculty of Medicine, Zanjan University of Medical Sciences, Zanjan, Iran; phone: +98911344632; e-mail: hfeizik@zums.ac.ir. 
bone, cartilage, and adipocytes (Bianco et al. 2001). BMSCs also support hematopoietic stem cells (HSCs) in bone marrow (Anthony and Link 2014).

Homeobox (Hox) genes are transcription factors that mainly regulate embryonic development (Svingen and Tonissen 2006). HOXB4, one of the Hox family genes, mostly is expressed in hematopoietic stem cells (Antonchuk et al. 2002). Multiple signaling pathways are involved in physiological actions of ghrelin while phosphatidylinositolbisphosphate 3-kinase (PI3K) and mitogen-activated protein kinase (MAPK) are among the best understood mediators (Chung et al. 2008; Chung et al. 2013; Yin et al. 2014). To find out the mechanism of HOXB4 upregulation by ghrelin, the aim of this study was to evaluate the involvement of PI3K and MAPK pathways in this effect of ghrelin.

\section{Material and methods}

BMSCs culture and drug treatments. All the experiments were carried out under the ethical guidelines of Zanjan University of Medical Sciences (IR.ZUMS.REC.1396.245). Male Wistar rat of 4-6 weeks were sacrificed under deep anesthesia using ketamine-xylazine ( $\mathrm{K}, 100 \mathrm{mg} / \mathrm{kg} ; \mathrm{X}, 10 \mathrm{mg} / \mathrm{kg}$ ). The lower limbs were removed with a pair of scissors separating it from the hip joint and put on a sterile gauze. The accompanied soft tissue (muscles, fasciae, and tendons) was removed, and femurs and tibiae were separated and put in a dish containing phosphate buffered saline (PBS, Gibco, Life Technologies, USA) and penicillin/streptomycin (Gibco, Life Technologies, USA). The dish was transferred under a laminar hood. The bones were subsequently washed again with PBS and put on a sterile gauze to dry. Both ends of the bones were cut, then with an insulin syringe containing high glucose Dulbecco's Modified Eagle Medium (DMEM, Gibco, Life Technologies, USA) and $1 \%$ penicillin/streptomycin, all the contents of the bone's lumen were flushed directly to $25 \mathrm{~cm}^{2}$ culture flask (SPL, life sciences, Korea) without any additional manipulation. The flushing

Table 1

Sequences of oligonucleotide primers

\begin{tabular}{ll}
\hline Name & Sequence $\left(\mathbf{5}^{\prime} \rightarrow \mathbf{3}^{\prime}\right)$ \\
\hline HOXB4 (Forward) & GCGACCATTACCTCGACACT \\
HOXB4 (Reverse) & GTTACCGTGGCCAAAACACT \\
$\beta$-actin (Forward) & CATGTACGTTGCTATCCAGGC \\
$\beta$-actin (Reverse) & CTCCTTAATGTCACGCACGAT \\
\hline
\end{tabular}

was done several times, so that the lumen became pale. Rat BMSCs were initially cultivated in DMEM (Dulbecco's Modified Eagle Medium), supplemented with $20 \%$ FBS (Gibco), $100 \mathrm{U} / \mathrm{ml}$ penicillin, and $100 \mathrm{mg} / \mathrm{ml}$ streptomycin in 4 experimental groups as B (untreated BMSCs), BG (BMSCs treated with $100 \mu \mathrm{M}$ ghrelin), PD (BMSCs treated with $10 \mu \mathrm{M}$ PD98059 and $100 \mu \mathrm{M}$ ghrelin) and LY (BMSCs treated with $10 \mu \mathrm{M}$ LY294002 and $100 \mu \mathrm{M}$ ghrelin). The cells were incubated at $37^{\circ} \mathrm{C}\left(5 \% \mathrm{CO}_{2}\right)$ in $25 \mathrm{~cm}^{2}$ plastic flask. The medium refreshed every 2-3 days until cells became confluent. The cells were harvested with trypsin-EDTA and passaged up to three times. To induce BMSCs, ghrelin (Tocris Bioscience Co., Bristol, UK) was freshly prepared. Passage 3 BMSCs were cultured in 96-well plates (5000 cells/well) in DMEM medium supplemented with ghrelin $100 \mu \mathrm{M}$ for $48 \mathrm{~h}$. To assay the effect of kinase inhibitor on HOXB4 gene expression, BMSCs were pretreated with ERK inhibitor PD98059 $(10 \mu \mathrm{M})$ and PI3K inhibitor LY294002 (10 $\mu \mathrm{M})$ (Sigma-Aldrich, USA) for $3 \mathrm{~h}$ prior to treatment with ghrelin.

Real-time PCR. Real-time PCR was carried out with RNA from Control (untreated BMSCs), BG (BMSCs treated with $100 \mu \mathrm{M}$ ghrelin), PD (BMSCs treated with $10 \mu \mathrm{M}$ PD98059) and LY (BMSCs treated with $10 \mu \mathrm{M}$ LY294002) and Synergic or SY (BMSCs treated with $10 \mu \mathrm{M}$ LY294002 plus $10 \mu \mathrm{M}$ PD98059, and $100 \mu \mathrm{M}$ ghrelin) groups. In all groups, $1000 \mathrm{ng}$ purified RNA from cultured cells was used to synthesize $20 \mu \mathrm{l} \mathrm{cDNA}$, using Revert aid ${ }^{\mathrm{TM}}$ first strand cDNA synthesis kit (Fermentas, Germany) according to the manufacturer's instructions. cDNA (25 ng) was used to quantify HOXB4 mRNA levels. As an internal control, primers for $\beta$-actin were used. All primers have been listed in Table 1 . The PCR reaction was synthesized in a $12.5 \mu \mathrm{l}$ volume (sense and anti-sense primers, cDNA, Sybr green,) and carried out for 40 cycles (Applied Biosystems cycler). For analyzing relative changes in mRNA levels, we used the delta CT method (Pfaffl method).

Immunostaining. BMSCs were cultured on cover slides and fixed in 3\% paraformaldehyde for $20 \mathrm{~min}$ at RT, followed by a permeabilization step in $100 \%$ methanol for $30 \mathrm{~min}$ at room temperature (RT). For immunofluorescence, BMSCs were incubated with anti-CD90 monoclonal antibody, followed by incubation with a fluorescein isothiocyanate (FITC)-conjugated rabbit anti-mouse antibody (Millipore). Nuclei were counterstained with DAPI. For indirect immunoperoxidase labeling, passage $3^{\text {rd }}$ BMSCs (for $48 \mathrm{~h}$ ) were permeabilized with $0.4 \%$ Triton X-100, followed by FCS $10 \%$ for 60 min to block endogenous peroxi- 
dase. Then BMSCs were incubated with anti-CD90 monoclonal antibodies (dilution 1/100; Abcam) overnight at $4{ }^{\circ} \mathrm{C}$, followed by incubation with a fluorescein isothiocyanate (FITC)-conjugated rabbit anti-mouse antibody (dilution 1/300, Millipore) for $4 \mathrm{~h}$ at RT.

Statistical analysis. Relative gene expression changes between cDNA samples were determined using Relative expression software tool 9 (REST 9, Qiagen), in which the $\beta$-actin gene was used as internal control. All data were expressed as means \pm Standard Error of the Mean (SEM). One-way ANOVA followed by Tukey's post hoc was used to compare multiple means in groups. The level of significance was set at $\mathrm{p}<0.05$.

\section{Results}

BMSCs expansion and identification. The primary culture of the isolated BMSCs is presented at Figures $1 \mathrm{~A}, \mathrm{D}$. The results showed that after $12 \mathrm{~h}$, the cells were attached to the flask and most of them were rounded (Figure 1A). Adherent cells were cultured and became heterogeneous after 12 or 16 days (passage 4) (Figure 1D). Following, the cells were
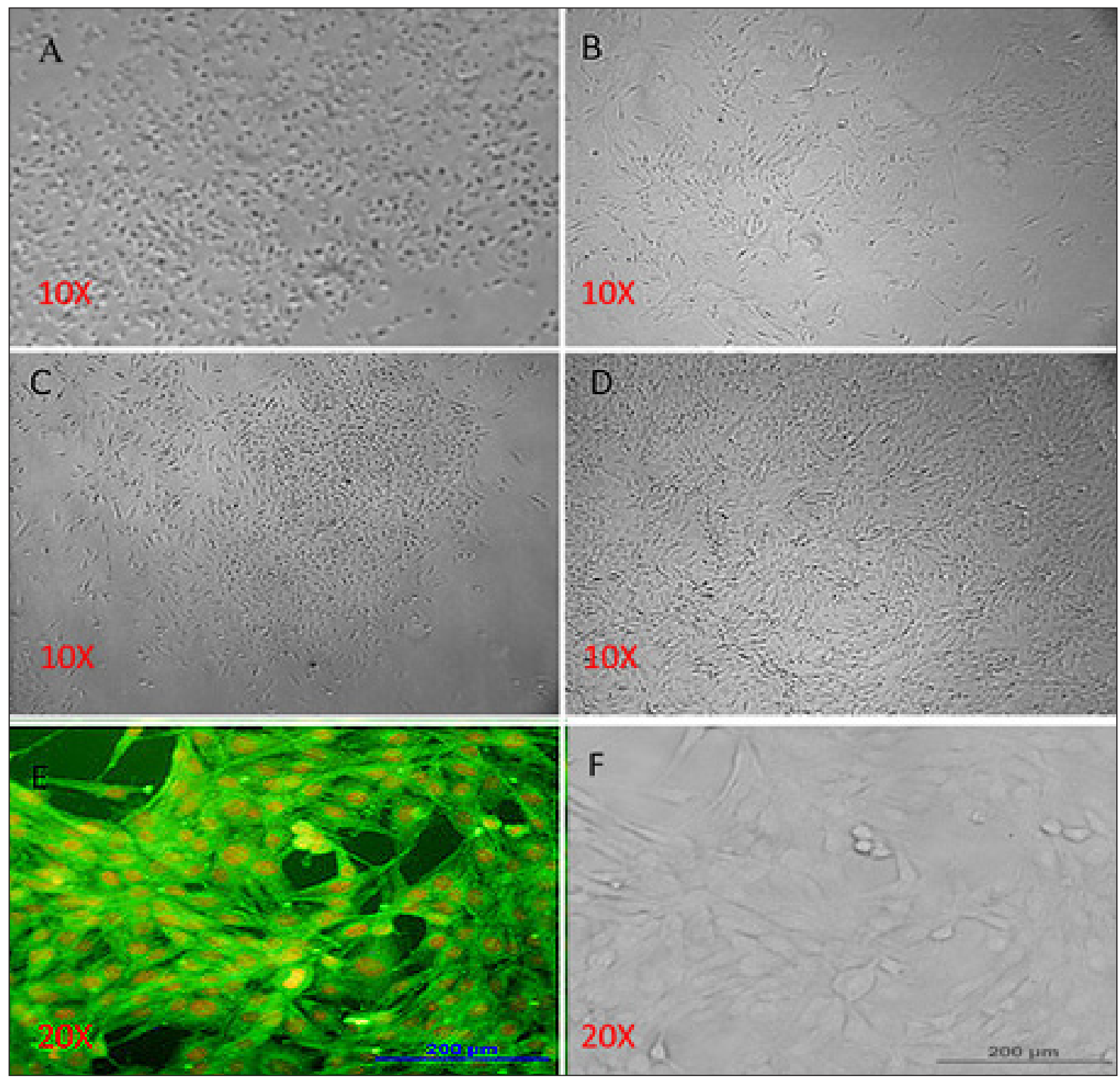

Figure 1. Micrographs of bone marrow stromal cells (BMSCs). (A) Primary culture of the BMSCs had round shapes (after $12 \mathrm{~h}$ ). (B) The cells are fibroblast-like cells after $48 \mathrm{~h}$. (C) Cells at the stage of the first passage and formation of colonies. (D) BMSCs have a more uniform spindle shape after 4 passages. (E, F) Immunostaining of CD90 and phase contrast micrographs of BMSCs at same field, respectively. The cells were immunostained with relevant primary antibodies and labeled with FITC-conjugated secondary antibody (green color shows positive cells) and the red colors are ethidium bromide counterstaining of the nuclei. 
immunostained with anti-CD90 (mesenchymal stem cells markers) antibody and incubated with FITCconjugated secondary antibody. The result showed that $100 \%$ of the cells were immunoreactive to CD90 (Figures 1E, F).

Effect of ghrelin on HOXB4 gene expression rates. The results of the mRNA expression pattern have been shown in the (Figure 2). Our data showed that mRNA expressions of HOXB4 gene significantly increased when ghrelin $100 \mu \mathrm{M}$ was used (BG; $16.39 \pm 6.36)$ as compare to the control group $(\mathrm{p}<0.05)$.

Effect of PD98059 and LY294002 on HOXB4 gene expression rates. As presented in Figure 2, although PD98059 $(10 \mu \mathrm{M})$ co-treatment with ghrelin $(100 \mu \mathrm{M})$ decreased HOXB4 gene expression, (PD; 2.6 \pm 0.27 ) as compare to the BG group $(16.39 \pm 6.36)$, but the decrease was not significant $(p=0.66)$. However, LY294002 $(10 \mu \mathrm{M})$ significantly reversed ghrelininduced overexpression of HOXB4, (LY; 0.4 \pm 0.22 ) as compare to the BG group $(16.39 \pm 6.36)(\mathrm{p}<0.05)$. The difference between LY and PD group was not statistically significant. Moreover, combination of LY294002 and PD98059 in SY group did not change HOXB4 gene expression significantly as compared to BG group. But as compared SY with LY group, PD98059 treatment reversed LY294002-induced HOXB4 downregulation while added simultaneously.

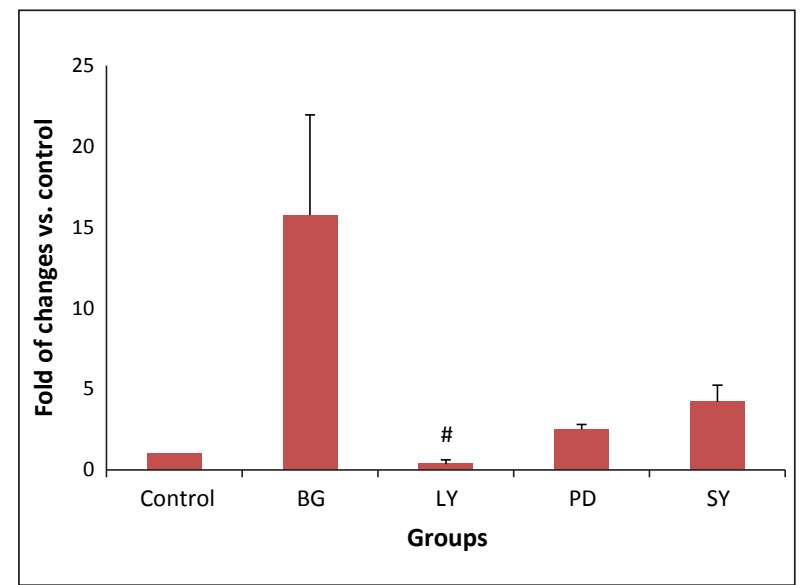

Figure 2. HOXB4 gene expression. Fold change ratio of HOXB4 mRNA of BMSCs treated with ghrelin $(100 \mu \mathrm{M})$ for 48 $\mathrm{h}$ and various experimental groups. Real-time PCR results are presented as relative expression normalized to $\beta$-actin mRNA amplification. Amplification of the HOXB4 mRNA derived from Control, BG, PD and LY groups. The bars indicate the mean \pm SEM. ${ }^{*} \mathrm{p}<0.05$ vs. Control group, $\# \mathrm{p}<0.05$ vs. $B G$ group. Control - untreated BMSCs; BG - BMSCs treated with ghrelin $(100 \mu \mathrm{M})$; PD - BMSCs treated with ghrelin $(100 \mu \mathrm{M})$ and PD98059 $(10 \mu \mathrm{M})$; LY - BMSCs treated with ghrelin $(100 \mu \mathrm{M})$ and LY294002 $(10 \mu \mathrm{M})$; SY - BMSCs treated with LY294002 $(10 \mu \mathrm{M})$, PD98059 $(10 \mu \mathrm{M})$, and ghrelin $(100 \mu \mathrm{M})$.

\section{Discussion}

Based on the data obtained in the present study, ghrelin upregulated HOXB4 gene expression in BMSCs and PI3K inhibition by LY294002 eliminated the promoting effect of ghrelin on the HOXB4 gene expression. Consequently, this effect of ghrelin on BMSCs could be mediated via the PI3K. We also found that inhibiting MAPK by PD98059 (10 $\mu \mathrm{M})$ could partially suppress the inducing effect of ghrelin on BMSCs, suggesting that other pathways may be involved in HOXB4 upregulation by ghrelin. In fact, depending on the inducer and/or the used cells the outcomes could be different. For example, it has been shown that thrombopoietin stimulates HOXB4 expression through MAPK pathway. This effect was not abolished by LY294002 and it means that the PI3K was not involved in the phenomenon (Kirito et al. 2003).

Furthermore, in the present study, there was no synergic effect observed while PD98059 was combined with LY294002, but oppositely PD98059 reversed the inhibitory effect of LY294002 on HOXB4 gene expression. It seems that the crosstalk between ERK and PI3K/Akt pathways leads to opposite regulation of HOXB4 expression in BMSCs. It is notable that according to some findings in the literature, there exists an interaction between MAPK and PI3K pathways and in some cases, they have contrary manners in their actions (Lee et al. 2006; Gan et al. 2010; Hu et al. 2012).

Several studies have shown that cAMP/PKA, PI3K/Akt and MAPK could be activated by ghrelin (Chung et al. 2008; Chung et al. 2013; Yin et al. 2014). PI3K/Akt pathway plays an important role in the physiological functions of ghrelin. In hepatoma cells, ghrelin increases insulin receptor substrate (IRS-1) associated PI3K activity and affects glucose transport (Murata et al. 2002). Moreover, it has been revealed that ghrelin through PI3K signaling controls cognitive aspects of feeding (Kanoski et al. 2013). It has been shown that PI3K/Akt contributes to the antiapoptotic effects of ghrelin in cardiomyocytes and primary cultured rat neuronal cells (Baldanzi et al. 2002; Chung et al. 2011). Ghrelin has also been shown to inhibits the apoptosis of the adipose-derived mesenchymal stem cells (ADMSCs) both in vitro and engrafted in ischemic heart through PI3K/Akt pathway (Han et al. 2015).

BMSCs, as a source of mesenchymal stem cells, are used in cell therapy ( $\mathrm{Hu}$ et al. 2008; Bi et al. 2015). However, they may suffer during transplantation due to oxidative stress before accommodation to new condition (Potier et al. 2007). Previously, we 
have shown that ghrelin improves BMSCs survival through regulating the $\mathrm{Bcl} 2$ and Caspase 3 gene expression in vitro (Abdanipour et al. 2017; Abdanipour et al. 2018b). Accordingly, PI3K/Akt signaling could be the possible mechanism of the ghrelin's effect on BMSCs proliferation and apoptosis.

Some research groups have indicated that overexpression of HOXB4 inhibits apoptotic cell death especially in hematopoietic cells (Antonchuk et al. 2001; Daniels et al. 2010; Park et al. 2012). Regarding to our previous findings, part of the anti-apoptotic effect of ghrelin in BMSCs could be due to HOXB4 overexpression in these cells. Another remarkable fact is that HoxB4 upregulation in embryonic stem cells could differentiate them to HSCs (Thorsteinsdottir et al. 1999; Lee et al. 2008; Jackson et al. 2012; Forrester and Jackson 2012). Whether HOXB4 overexpression by ghrelin also may contribute to the probable BMSCs differentiation to HSCs requires further research.

Taken together, we can conclude that ghrelin, through PI3K/Akt pathway may improve the BMSC transplantation potency by reducing its apoptosis. Moreover, upregulating HOXB4 in BMSC and its possible differentiation to HSCs, which needs to be proven by further investigations, could open the doors to new treatment for hematologic disorders. Therefore, activating the PI3K/Akt pathway, instead of using a non-specific inducer, could be the principal point to increase the efficiency of BMSC-based cell therapies in the future.

In conclusion, ghrelin upregulates HOXB4 gene expression in rat's BMSCs through PI3-kinase signaling pathway.

\section{Acknowledgements}

The results described in this paper were part of student thesis (Shokoufeh Taherkhani) for MSc degree in physiology. The authors would like to thank the Vice-Chancellery for Research affairs of Zanjan University of Medical Sciences for financial support (grant no. A-10-914-2).

\section{References}

Abdanipour A, Shahsavandi B, Dadkhah M, Alipour M, Feizi H. The antiapoptotic effect of ghrelin in the H2O2 treated Bone Marrow-derived Mesenchymal Stem cells of rat. J Zanjan Univ Med Sci Health Serv 25, 58-68, 2017.

Abdanipour A, Shahsavandi B, Alipour M, Feizi H. Ghrelin upregulates HOXB4 gene expression in the rat BMSCs. Cell J 20, 183-187, 2018a.

Abdanipour A, Dadkhah M, Alipour M, Feizi H. Effect of ghrelin on caspase 3 and Bcl2 gene expression in H2O2 treated rat's bone marrow stromal cells. Adv Pharm Bull 8, 429-435, 2018 b.

Albarran-Zeckler RG, Smith RG. The ghrelin receptors (GHS-R1a and GHS-R1b). Endocr Dev 25, 5-15, 2013.

Anthony BA, Link DC. Regulation of hematopoietic stem cells by bone marrow stromal cells. Trends Immunol 35 , 32-37, 2014.

Antonchuk J, Sauvageau G, Humphries RK. HOXB4 overexpression mediates very rapid stem cell regeneration and competitive hematopoietic repopulation. Exp Hemato 29, 1125-1134, 2001.

Antonchuk J, Sauvageau G, Humphries RK. HOXB4-induced expansion of adult hematopoietic stem cells ex vivo. Cell 109, 39-45, 2002.

Baldanzi G, Filigheddu N, Cutrupi S, Catapano F, Bonissoni S, Fubini A, Malan D, Baj G, Granata R, Broglio F, Papotti M, Surico N, Bussolino F, Isgaard J, Deghenghi R, Sinigaglia F, Prat M, Muccioli G, Ghigo E, Graziani A. Ghrelin and des-acyl ghrelin inhibit cell death in cardiomyocytes and endothelial cells through ERK1/2 and PI 3-kinase/AKT. J Cell Biol 159, 1029-1037, 2002.

Bi L, Wang G, Yang D, Li S, Liang B, Han Z. Effects of autologous bone marrow-derived stem cell mobilization on acute tubular necrosis and cell apoptosis in rats. Exp Ther Med 10, 851-856, 2015.

Bianco P, Riminucci M, Gronthos S, Robey PG. Bone marrow stromal stem cells: nature, biology, and potential applications. Stem Cells 19, 180-192, 2001.

Chung H, Seo S, Moon M, Park S. Phosphatidylinositol-3-kinase/Akt/glycogen synthase kinase-3 beta and ERK1/2 pathways mediate protective effects of acylated and unacylated ghrelin against oxygen-glucose deprivationinduced apoptosis in primary rat cortical neuronal cells. J Endocrinol 198, 511-521, 2008.

Chung H, Chung HY, Bae CW, Kim CJ, Park S. Ghrelin suppresses tunicamycin- or thapsigargin-triggered endoplasmic reticulum stress-mediated apoptosis in primary cultured rat cortical neuronal cells. Endocr J 58, 409-420, 2011. 
Chung H, Li E, Kim Y, Kim S, Park S. Multiple signaling pathways mediate ghrelin-induced proliferation of hippocampal neural stem cells. J Endocrinol 218, 49-59, 2013.

Daniels TR, Neacato II, Rodriguez JA, Pandha HS, Morgan R, Penichet ML. Disruption of HOX activity leads to cell death that canbe enhanced by the interference of iron uptake in malignant B cells. Leukemia 24, 1555-1565, 2010.

Forrester LM, Jackson M. Mechanism of action of HOXB4 on the hematopoietic differentiation of embryonic stem cells. Stem Cells 30, 379-385, 2012.

Gan Y, Shi C, Inge L, Hibner M, Balducci J, Huang Y. Differential roles of ERK and Akt pathways in regulation of EGFR-mediated signaling and motility in prostate cancer cells. Oncogene 29, 4947-4958, 2010.

Han D, Huang W, Ma S, Chen J, Gao L, Liu T, Zhang R, Li X, Li C, Fan M, Chen Y, Cao F. Ghrelin improves functional survival of engrafted adipose-derived mesenchymal stem cells in ischemic heart through PI3K/Akt signaling pathway. Biomed Res Int 2015, 858349, 2015.

Hu X, Yu SP, Fraser JL, Lu Z, Ogle ME, Wang JA, Wei L. Transplantation of hypoxia-preconditioned mesenchymal stem cells improves infarcted heart function via enhanced survival of implanted cells and angiogenesis. J Thorac Cardiovasc Surg 135, 799-808, 2008.

Hu C, Huang L, Gest C, Xi X, Janin A, Soria C, Li H, Lu H. Opposite regulation by PI3K/Akt and MAPK/ERK pathways of tissue factor expression, cell-associated procoagulant activity and invasiveness in MDA-MB-231 cells. J Hematol Oncol 5, 16, 2012.

Jackson M, Axton RA, Taylor AH, Wilson JA, Gordon-Keylock SA, Kokkaliaris KD, Brickman JM, Schulz H, Hummel O, Hubner N, Forrester LM. HOXB4 can enhance the differentiation of embryonic stem cells by modulating the hematopoietic niche. Stem Cells 30, 150-160, 2012.

Kanoski SE, Fortin SM, Ricks KM, Grill HJ. Ghrelin signaling in the ventral hippocampus stimulates learned and motivational aspects of feeding via PI3K-Akt signaling. Biol Psychiatry 73, 915-923, 2013.

Kirito K, Fox N, Kaushansky K. Thrombopoietin stimulates Hoxb4 expression: an explanation for the favorable effects of TPO on hematopoietic stem cells. Blood 102, 3172-3178, 2003.

Kojima M, Kangawa K. Ghrelin: structure and function. Physiol Rev 85, 495-522, 2005.

Lee ER, Kim JY, Kang YJ, Ahn JY, Kim JH, Kim BW, Choi HY, Jeong MY, Cho SG. Interplay between PI3K/Akt and MAPK signaling pathways in DNA-damaging drug-induced apoptosis. Biochim Biophys Acta 1763, 958-968, 2006.

Lee GS, Kim BS, Sheih JH, Moore MA. Forced expression of HoxB4 enhances hematopoietic differentiation by human embryonic stem cells. Mol Cells 25, 487-493, 2008.

Li E, Chung H, Kim Y, Kim DH, Ryu JH, Sato T, Kojima M, Park S. Ghrelin directly stimulates adult hippocampal neurogenesis: implications for learning and memory. Endocr J 60, 781-789, 2013.

Mahmood A, Lu D, Chopp M. Marrow stromal cell transplantation after traumatic brain injury promotes cellular proliferation within the brain. Neurosurgery 55, 1185-1193, 2004.

Moon M, Kim S, Hwang L, Park S. Ghrelin regulates hippocampal neurogenesis in adult mice. Endocrine J 56, 525-531, 2009.

Murata M, Okimura Y, Iida K, Matsumoto M, Sowa H, Kaji H, Kojima M, Kangawa K, Chihara K. Ghrelin modulates the downstream molecules of insulin signaling in hepatoma cells. J Biol Chem 277, 5667-5674, 2002.

Park SW, Won KJ, Lee YS, Kim HS, Kim YK, Lee HW, Kim B, Lee BH, Kim JH, Kim DK. Increased HoxB4 inhibits apoptotic cell death in Pro-B cells. Korean J Physiol Pharmacol 16, 265-271, 2012.Potier E, Ferreira E, Meunier A, Sedel L, Logeart-Avramoglou D, Petite H. Prolonged hypoxia concomitant with serum deprivation induces massive human mesenchymal stem cell death. Tissue Eng 13, 1325-1331, 2007.

Svingen T, Tonissen KF. Hox transcription factors and their elusive mammalian gene targets. Heredity 97, 88-96, 2006.

Thorsteinsdottir U, Sauvageau G, Humphries RK. Enhanced in vivo regenerative potential of HOXB4-transduced hematopoietic stem cells with regulation of their pool size. Blood 94, 2605-2612, 1999.

van der Lely AJ, Tschop M, Heiman ML, Ghigo E. Biological, physiological, pathophysiological, and pharmacological aspects of ghrelin. Endocr Rev 25, 426-457, 2004.

Yang J, Liu GQ, Wei R, Hou WF, Gao MJ, Zhu MX, Wang HN, Chen GA, Hong TP. Ghrelin promotes differentiation of human embryonic stem cells into cardiomyocytes. Acta Pharmacol Sin 32, 1239-1245, 2011.

Yin Y, Li Y, Zhang W. The growth hormone secretagogue receptor: its intracellular signaling and regulation. Int J Mol Sci 15, 4837-4855, 2014. 